\title{
Fat-tailed sheep in Indonesia; an essential resource for smallholders
}

\author{
Henk Mathijs Johannes Udo • \\ I. Gede Suparta Budisatria
}

Accepted: 12 April 2011 / Published online: 27 April 2011

(C) The Author(s) 2011. This article is published with open access at Springerlink.com

\begin{abstract}
This paper discusses the historical development of fat-tailed sheep in Indonesia, the dynamics of production systems, production and reproduction performances under farmers' conditions, and roles of sheep in livelihoods. In the eighteenth and nineteenth century, fat-tailed sheep from southwest Asia and Africander sheep from South Africa were introduced. Crossing of fat-tailed sheep with the local thin-tailed sheep produced the Javanese fat-tailed sheep. Main motives for the gradual change-over to fat-tailed sheep have been their potential larger body size and the preference of consumers for their meat. Management systems are changing in response to the intensification of land use. The reproductive performances of fat-tailed sheep are good. Households keep four to six animals, housed close to the family quarters. This results in very high levels of faecal bacteria contamination of drinking water sources. Sheep provide a small income, manure, security and help to accumulate capital. Sheep also play a key role in religious festivities. Farmers hardly profit from the increased demand for the feast of sacrifice; animals are sold mainly when the owners have urgent cash needs. Systematic sheep fattening can contribute to higher economic results, if sufficient family labour and crop residues are available.
\end{abstract}

Keywords Java $\cdot$ Livelihoods · Production · Religious festivities $\cdot$ Reproduction $\cdot$ Sheep

\footnotetext{
H. M. J. Udo $(\bowtie)$

Animal Production Systems Group, Wageningen University, PO Box 338, 6700 AH Wageningen, The Netherlands

e-mail: henk.udo@wur.nl

I. G. S. Budisatria

Faculty of Animal Science, Gadjah Mada University,

Yogyakarta, Indonesia

e-mail: budisatria1968@yahoo.com
}

\section{Introduction}

In South East Asia, Indonesia has the largest small ruminant population. Small ruminant development programmes started about 90 years ago. At that time, there were about 2 million small ruminants (Barwegen 2005). At present, there are 15.7 million goats and 10.5 million sheep (Anonymous 2006). The increase in human population is a major driver for the increase in the small ruminant population. The majority of the sheep are fat-tailed sheep. They have gradually replaced the native thin-tailed sheep. About $90 \%$ of the sheep are on the island of Java, a densely populated island with intensive cropping systems. Mason (1978) concluded that the sheep of Java are an invaluable genetic resource, which should be treasured for their adaptation to a difficult environment and for their high rate of reproduction.

Nearly $99 \%$ of small ruminants are in hand of smallholders (Knipscheer et al. 1984; Soedjana 1993). They are easy to manage, have a ready market, act as a savings account in case farmers have urgent cash requirements, have socio-cultural roles and they produce manure to fertilise the land (Soedjana et al. 1988; Devendra 2002; Sarwono et al. 1993; Subandriyo 1998). The Indonesian government promotes intensification of small ruminant production to increase the animal protein consumption and to improve the income-situation of rural households. Agro-ecological conditions are believed to have an important impact on the type of small ruminants kept. Sheep are said to be suitable for the lowlands with some grazing areas and cropping systems dominated by rice and cassava. This gives farmers access to rice bran and cassava peelings. Sheep are considered to be the best choice to utilise these crop residues. Policy-makers and farmers perceive that goats need better quality feeds than sheep and that goats are 
more suitable for higher altitude areas with plantation crops and abundant tree leaves. Historically, development programmes in Indonesia focussed on goats rather than on sheep, irrespective of the agro-ecological conditions (Budisatria et al. 2007b).

In order to exploit the potential of sheep in rural development, it is necessary to understand the constraints and opportunities for smallholder sheep production. This paper discusses the historical development of fat-tailed sheep in Indonesia, the dynamics of production systems, production and reproduction performances under farmer's conditions, and roles of sheep in livelihoods.

\section{Fat-tailed sheep evolution}

In the eighteenth and nineteenth century, during the Dutch administration, there was little interest in small ruminants (Barwegen 2005). Arab traders brought fat-tailed sheep from southwest Asia. In 1731, the government imported fat-tailed Kirmani (also known as Baluchi) males from Persia. In 1754 and 1779, importers were offered subsidies to import fat-tailed sheep, but there is no evidence that imports took place (Mason 1980; Barwegen 2005). In 1802, 'Cape' sheep, probably fat-tailed Africanders from South Africa, were found around the capital (Mason 1978). During the 1860s, there were several imports of Merinos from Australia. They were crossed with Africanders and with local thin-tailed sheep by sheep breeders around Garut in West Java. Other imports of Australian Merinos took place in 1897, 1903, and 1906 and of Romney Marsh in 1912 and 1914 (Mason 1980). Later, the Texel breed was imported by the Dutch. During the 1970s, e.g. Suffolk, Dormer (Dorset $\times$ Merino) and Suffmer (Suffolk $\times$ Merino) were introduced. These introductions had hardly any influence on the existing small ruminant population.

In the period of the economic crisis in the $1920 \mathrm{~s}$, the government became more interested in small ruminants (Barwegen 2005). In the island of Madura, in 1938, a breeding farm for fat-tailed sheep was established. Since then, fat-tailed sheep became well established in Madura from where they spread into East Java, and later to other parts of Java. The crossing of the fat-tailed sheep with the native thin-tailed sheep produced the Javanese fat-tailed sheep (Fig. 1). There is no information regarding the exact numbers of each type of sheep and goats in Indonesia, but the majority (from about $50 \%$ in West Java to $80 \%$ in East Java) of all sheep on Java are now Javanese fat-tailed sheep (Anonymous 2006).

The change from thin-tailed sheep to fat-tailed sheep was done by the farmers themselves without any interference from the government. Major driving forces for this change have been the preference of farmers for animals with a larger body size and the consumer preferences for meat of fat-tailed sheep and of the tail in particular (Mason 1980). The Javanese fat-tailed sheep are white and hornless. The Garut or Priangan sheep from West Java, the cross of local thin-tailed sheep with Merino and fat-tailed sheep, are white or black. They have some fat at the base of the tail. The black-coloured sheep are kept for ram fighting. The Garut males have spiral horns (DGLS 2003). Mason (1978) did not categorise them as fat-tailed sheep.

\section{Sheep farming systems}

In the past, small ruminants depended on grazing only (Robinson 1977). The intensification of land use forces small ruminant keepers to change from grazing towards cut-and-carry feeding (Palte 1989). Sheep are said to be primarily suitable for grazing, but grazing alone is rarely practised any more. The majority of small ruminants are now kept in confinement or in a combination of grazing and confinement. In Central Java, in the lowlands $(<100 \mathrm{~m}$ above sea level, asl), it is estimated that $76 \%$ of the sheep are still able to graze, whereas in the middle zone (100$500 \mathrm{~m}$ asl) and uplands (>500 $\mathrm{m}$ asl), around $60 \%$ of the sheep farmers still graze their sheep (Budisatria et al.

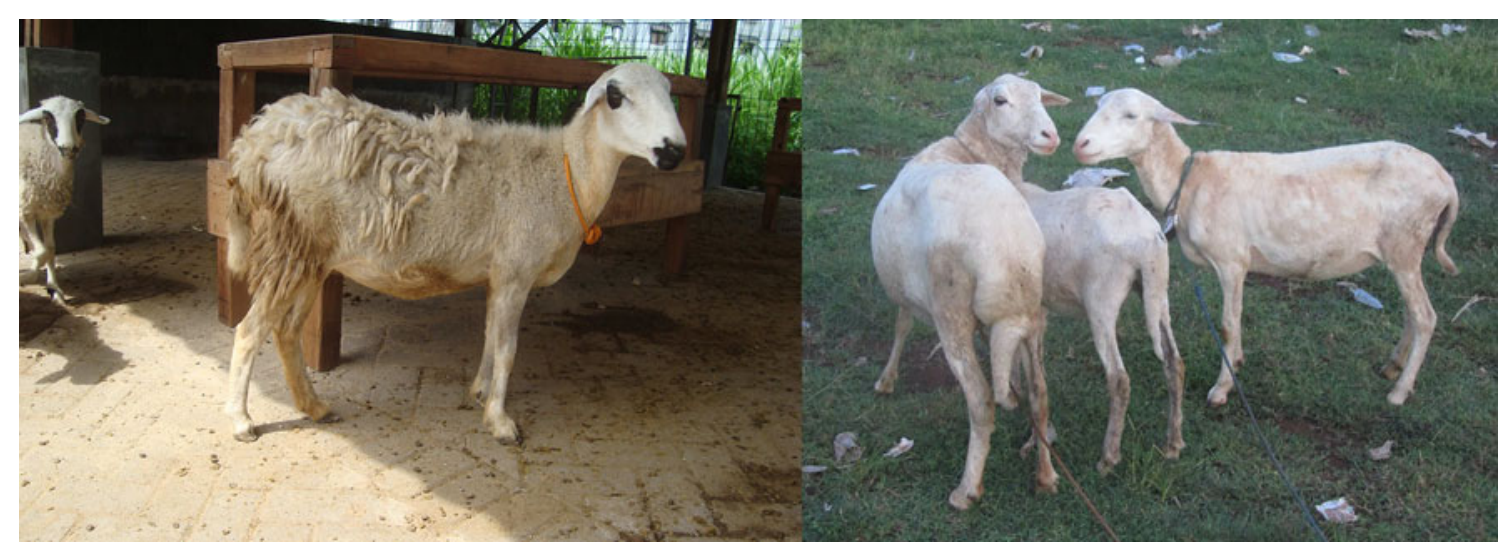

Fig. 1 Javanese thin-tailed (left) and fat-tailed (right) sheep 
2007b). In West Java, most sheep are housed; whereas in Madura, sheep are grazing during the daytime.

Farmers usually keep four to six sheep. In Central Java, the flocks consisted for $53 \%$ of ewes, $16 \%$ rams and $31 \%$ lambs (Budisatria 2006). Ewes are kept until they are about 4 years old (Mason 1980). The old females are difficult to mate because of the fat tail (Mason 1980).

In Central Java, small ruminant farmers were on average 50 years old and had 10-25 years experience in keeping animals. The average hour of family labour per day for small ruminants was 3.8. Men were mostly responsible for feed collection and marketing (on average $1.9 \mathrm{~h} \mathrm{day}^{-1}$ ), whereas cleaning the sheds was the responsibility of women $\left(1.2 \mathrm{~h} \mathrm{day}^{-1}\right)$. The involvement of children $(0.6 \mathrm{~h}$ day $^{-1}$ ) depended on their time available (Budisatria et al. 2007b).

Small ruminants' sheds are usually very close to the family quarters. This can pose a pollution threat. In Central Java, small ruminants had little impact on air quality inside and around small ruminants' sheds (Budisatria et al. 2007a), although neighbouring households complained about the odour from small ruminant manure (Budisatria et al. 2007b). The water sources had very high levels of faecal coliform bacteria and total coliform bacteria, two groups of bacteria used as indicators for water contamination caused by manure (Budisatria et al. 2007a).

Animal diseases are not considered to be a main problem (Mason 1978). The use of slatted floors helps to prevent foot rot problems. Haemonchosis is a major parasite problem (Mason 1978). Data from a slaughterhouse in West Java showed that $82 \%$ of the sheep were infected with Haemonchus contortus (Gatenby et al. 1988). Research from Sumatra, where sheep are grazed in rubber plantations, suggested that almost all sheep had parasites, but that some sheep seem to be resistant and consistently show zero or low parasite egg counts (Gatenby et al. 1995).

The marketing of small ruminants involves many stakeholders (Budisatria et al. 2008). Farmers possess minimal marketing information and usually complain about the prices they receive. In Java, small ruminant markets are organised every 5 days. Farmers sell their animals through the local village collector. This person takes them to the small ruminant market. Traders operate between small ruminant markets. Prices are based on visual appraisal of the animal and an estimate of the body weight. Traders have small trucks in which they transport the animals; some traders transport the animals to the capital. The buyers from these traders can be small vendors, retail butchers or consumers. Consumers are often individuals who intend to celebrate the birth of a child. During Idul Adha, the Moslem feast of sacrifice, roadside sellers and mosques are also involved in the marketing system. Most consumers buy their small ruminant meat from traditional sources, the younger generation, however, seems to prefer to buy their meat from supermarkets (Nasrullah et al. 2010).

\section{Feeding practices}

Sheep are fed with field grass and crop residues. In Central Java, about $60 \%$ of the fresh feeds fed was grass collected from roadsides, field borders, paddy field dykes, football fields and other communal resources. In the lowlands, cassava peelings made up $30 \%$ of the diet both in the dry and wet season. In the other agro-ecological zones, also sheep were fed with leaves (e.g. leaves of legume and fruit trees, hibiscus). In the dry season, all sheep farmers fed small amounts of rice bran. The average dry matter (DM) intake of the feeds provided was estimated at $1.25 \mathrm{~kg} \mathrm{days}^{-1}$, and the crude protein (CP) intake at $0.13 \mathrm{~kg} \mathrm{days}^{-1}$. There were no significant differences in intakes of sheep between seasons or agro-ecological zones (Budisatria et al. 2010).

The most common grazing areas are fallow fields, roadsides and football fields. Farmers bring their animals to these fields and take them home at midday when they return from their activities in the fields. In Central Java, the daily grazing hours (for sheep given the opportunity to graze) varied from 4.1 in the lowlands to 3.5 in other zones. The DM and CP intakes of feeds provided were only $1-2 \%$ lower in small ruminants being able to graze and small ruminants not being able to graze (Budisatria et al. 2010). Sheep are fed early in the morning before they are taken out for grazing, they are not taken out for grazing every day, and they are only allowed to graze in the dry season when there is not much grazing available. In the wet season, farmers do not graze small ruminants, because they are afraid of bloat and of internal parasites. So, in Central Java, grazing was not a major component in the sheep diet, contrary to the common perception that grazing is very important for sheep. Grazing, however, gives exercise for sheep and gives farmers the opportunity to clean the sheds (Budisatria et al. 2010).

\section{Production and reproduction performances}

Table 1 gives an overview of production performances of fat-tailed sheep under field conditions. In general, sheep are mated at an age just over 1 year. Lambs are weaned at an age of 3 months and ewes are mated again 4 months after parturition. In an intensive cropping area with abundant crop residues, first mating took place much earlier and the postpartum mating interval was only 81 days (Yulianto 2007). About 1.7 services are needed per conception. In general, litter sizes at birth vary from 1.5 to 1.9 . In the island of Madura, under intensive management systems, the reproductive performance of fat-tailed sheep was low, probably due to the size of the tails of well-fed ewes (Obst 
Table 1 Selected information on fat-tailed sheep production performances under farmers' conditions

\begin{tabular}{|c|c|c|c|}
\hline Performance parameter & Value & Production system & Source \\
\hline \multirow[t]{4}{*}{ First mating (month) } & 13.6 & Lowlands, Central Java (CJ) & \multirow[t]{3}{*}{ Budisatria et al. 2010} \\
\hline & 13.4 & Middle zone, CJ & \\
\hline & 12.2 & Uplands, CJ & \\
\hline & 7.7 & Intensive, lowlands, CJ & Yulianto 2007 \\
\hline \multirow[t]{4}{*}{ Weaning (days) } & 102 & Lowlands, CJ & \multirow[t]{3}{*}{ Budisatria et al. 2010} \\
\hline & 89 & Middle zone, CJ & \\
\hline & 92 & Uplands, CJ & \\
\hline & 91 & Intensive, lowlands, CJ & Yulianto 2007 \\
\hline \multirow[t]{4}{*}{ Post partum mating interval (days) } & 130 & Lowlands, CJ & \multirow[t]{3}{*}{ Budisatria et al. 2010} \\
\hline & 115 & Middle zone, CJ & \\
\hline & 122 & Uplands, CJ & \\
\hline & 81 & Intensive, lowlands, CJ & Yulianto 2007 \\
\hline \multirow[t]{5}{*}{ Parturition interval (days) } & 279 & Lowlands, CJ & \multirow[t]{3}{*}{ Budisatria et al. 2010} \\
\hline & 264 & Middle zone, CJ & \\
\hline & 271 & Uplands, CJ & \\
\hline & 250 & Intensive, Madura & Obst et al. 1980 \\
\hline & 243 & Intensive, lowlands, CJ & Yulianto 2007 \\
\hline \multirow[t]{4}{*}{ Services per conception $(n)$} & 1.9 & Lowlands, CJ & \multirow[t]{3}{*}{ Budisatria et al. 2010} \\
\hline & 1.6 & Middle zone, CJ & \\
\hline & 1.7 & Uplands, CJ & \\
\hline & 1.5 & Intensive, lowlands, CJ & Yulianto 2007 \\
\hline \multirow[t]{7}{*}{ Litter size $(n)$} & 1.5 & Lowlands, CJ & \multirow[t]{3}{*}{ Budisatria et al. 2010} \\
\hline & 1.6 & Middle zone, CJ & \\
\hline & 1.6 & Uplands, CJ & \\
\hline & 1.9 & Intensive, lowlands, CJ & Yulianto 2007 \\
\hline & 1.0 & Intensive, Madura & Obst et al. 1980 \\
\hline & 2.4 & Uplands, East Java (EJ) & Winantea and Udo 1988 \\
\hline & 1.6 & Middle zone, EJ & \\
\hline \multirow[t]{4}{*}{ Weaning (\%) } & 89 & Lowlands, CJ & \multirow[t]{3}{*}{ Budisatria et al. 2010} \\
\hline & 92 & Middle zone, CJ & \\
\hline & 84 & Uplands, CJ & \\
\hline & 60 & Intensive, Madura & Obst et al. 1980 \\
\hline \multirow[t]{6}{*}{ Ewe weights (kg) } & 27 & Lowlands, CJ & \multirow[t]{3}{*}{ Budisatria et al. 2010} \\
\hline & 28 & Middle zone, CJ & \\
\hline & 28 & Uplands, CJ & \\
\hline & 26 & Uplands, EJ & \multirow[t]{2}{*}{ Winantea and Udo 1988} \\
\hline & 26 & Middle zone, EJ & \\
\hline & 26 & Lowlands, CJ & Hernandez 2006 \\
\hline \multirow[t]{3}{*}{ Young ram weights (kg) } & 28 & Lowlands, CJ & \multirow[t]{3}{*}{ Budisatria et al. 2010} \\
\hline & 29 & Middle zone, CJ & \\
\hline & 29 & Uplands, CJ & \\
\hline \multirow[t]{4}{*}{ Growth rates $\left(\mathrm{g} \mathrm{day}^{-1}\right)$} & 97 & 0-3 months, CJ & \multirow[t]{4}{*}{ Budisatria et al. 2010} \\
\hline & 78 & 3-6 months, CJ & \\
\hline & 53 & 6-12 months, CJ & \\
\hline & 35 & $>12$ months, CJ & \\
\hline
\end{tabular}

et al. 1980). Therefore, some farmers are docking the female tail or farmers move the tail of the ewe away from the vulva as the ram mounts. In East Java, Winantea and Udo (1988) found a very high litter size at birth of 2.4 in a high altitude area with cool temperatures, compared to 1.6 in a medium altitude area. Farmers prefer singles or twins because the larger litters take up a lot of time and care, and there is high mortality among lambs from larger litters (Winantea and Udo 1988; Rachman et al. 2001). The reproductive performances confirm Mason's (1978) statement that the fat-tailed sheep of Java are prolific. The number of lambs weaned per ewe per year comes close to 
two, except for intensive management systems, such as in Madura.

Female adult weights vary only from 26 to $28 \mathrm{~kg}$, although, mature ewe weights of $35 \mathrm{~kg}$ have been recorded (Sodiq and Tawfik 2004). In Central Java, weights of young (15 months) rams were about $29 \mathrm{~kg}$. Weights of old rams can go up to $40-60 \mathrm{~kg}$. The Central Java data show that growth rates were highest for suckling lambs $\left(97 \mathrm{~g} \mathrm{day}^{-1}\right)$, followed by young weaners, 6-12-month old lambs and sheep older than 12 months. The opportunity to graze more in the lowlands did not result in better growth rates of sheep in this agro-ecological zone. On average, all sheep types were growing at a rate of $65 \mathrm{~g}_{\text {day }}{ }^{-1}$ (Budisatria et al. 2010). Sodiq and Tawfik (2004) found a slightly lower growth rate for fat-tailed sheep $\left(48 \mathrm{~g} \mathrm{day}^{-1}\right)$.

In Indonesia, different authors found that growth performances of sheep can be increased with relatively low levels of supplementation of rice bran (Basuno and Petheram 1982; Martawidjaja et al. 1982; Pond et al. 1994; Budisatria 1996; Merkel et al. 1999). Average daily gains of lambs can be increased to about $150 \mathrm{~g}$ day $^{-1}$ per head by increasing the level of rice bran supplementation from the actual feeding level of about 130-300 $\mathrm{g} \mathrm{day}^{-1}$ (Budisatria 2006).

Fat-tailed sheep and livelihoods

Farmers state that there are three main motives for keeping sheep: financial security, manure and cash income. Added to this, sheep play an important role in religious festivities of the majority of the population.

\section{Economic contributions}

Estimates of the contribution of small ruminants to farm incomes vary from $14 \%$ to $17 \%$ (in West Java; Knipscheer et al. 1983) to $25 \%$ (sheep in rubber plantation; Knipscheer et al. 1983) and 30\% (for really poor households in Central Java; Asikin 2001). These estimates are based on costs and revenues. Households consider their sheep as an activity that helps them to accumulate capital and gives them the opportunity to obtain cash in periods of urgent cash needs, which is mainly at the end of the dry season when they need money for preparing their paddy fields. This coincides with the start of the school year, when households need cash for school fees. In Central Java, a comprehensive assessment of the various contributions of sheep to livelihoods was based on the 'value added' (revenues of the sale of stock, the increase in flocks and the fertiliser value of manure minus variable costs) plus estimates of 'additional benefits' (Budisatria et al. 2010). The additional benefits represent the money saved by a household in a flock as guarantee that future requirements can be met, equivalent to an insurance premium not required, and the expenses avoided by selling animals for urgent cash needs, i.e. saving of financing expenses incurred by engaging formal or informal agents. The total economic benefits for a household from sheep varied from $120 €$ year $^{-1}$ in the middle zone to $130 €$ year $^{-1}$ in the uplands in Central Java (Budisatria et al. 2010). In the lowlands, the differences in economic performances between goat and sheep flocks were slightly in favour of sheep, whereas in the uplands, the benefits of goat flocks were $25 \%$ higher than those of sheep flocks due to slightly larger goat flocks, larger litters in goats and higher prices for goat breeding stock. The returns per unit of family labour from sheep keeping were about one quarter below the minimum labour wage. A main reason for this was the high labour demand for daily management (mainly feed collection and cleaning the sheds). Farmers with sufficient family labour, however, do not consider the use of family labour as a production cost, because alternative employment opportunities are limited.

\section{Manure}

Farmers often collect forages in quantities greatly in excess of the requirements. This can go up to about $40 \%$ (Tanner et al. 2001). This offers the possibility for animals to select, but the main reason is that it gives farmers the opportunity to compost the refused feeds with manure. The majority of small ruminants are kept on slatted floors over deep pits where excess feed, faeces and urine accumulate. The accumulation of layers of faeces and uneaten forage in the pit also helps to limit $\mathrm{N}$ loss by reducing the volatilisation of ammonia (Tanner et al. 2001). The manure is stored for $3-$ 6 months. It is used to fertilise paddy fields and fruit trees. Manure is not traded, which indicates that farmers value manure for their own use and that the amounts produced are not in excess of what is needed (Budisatria et al. 2007b). Manure or compost is not sufficiently available to totally replace inorganic fertilisers. It is often used in combination with inorganic fertilisers. Farmers assume that small ruminants manure has a higher quality than other manure.

\section{Religion}

Each Moslem family with a higher living standard is obliged to slaughter a sheep or a goat during the Idul Adha, feast of sacrifice, celebration (Subandriyo 1998; Jabbar 1998). The time interval between Idul Adha is about 355 days. It is part of the ceremonies of the great pilgrimage. Mosques coordinate the distribution of meat among the poor in the society and the people who have sacrificed. Families prefer to slaughter sheep over goats as sacrificial offerings during Idul Adha. This could be related to a preference for fat meat (Thys and Wilson 1996). The 
Idul Adha market requires males of at least $25 \mathrm{~kg}$ body weight.

In West Java, in 1982, Soedjana reported that prices increase by as much as $25 \%$ during Idul Adha. In Central Java, 20 years later, the prices of sheep increased $40-100 \%$ during the weeks before Idul Adha (Budisatria et al. 2008). The major reason for this high increase in prices in Central Java is that the number of people with a higher living standard has considerably increased over the past two decades. The higher prices of sheep before Idul Adha were based on a $42 \%$ higher body weight of animals offered for sale and a $20 \%$ higher price per kilogram during the $I d u l$ Adha period (Budisatria et al. 2008).

Farmers hardly profit from the increased Idul Adha demand. In Central Java, only about $20 \%$ of the farmers sold small ruminants during the Idul Adha celebration (Budisatria et al. 2008). The small number of animals they keep makes it too difficult to plan the sale of males with a minimum body weight of $25 \mathrm{~kg}$ during the period when the prices increase. Scenario studies indicated that matching sheep fattening to the Idul Adha demand, based on rice bran supplementation, is theoretically possible (Budisatria et al. 2008). This resulted in $32-55 \%$ higher economic benefits than from the present production system and the returns to labour were comparable to the minimum labour wage. The number of sheep that households can fatten, however, is limited due to lack of family labour and feed sources (Budisatria et al. 2008).

\section{Development programmes}

During the Dutch colonial period, a major increase in small ruminant numbers occurred between 1920 and 1940 and coincided with a steep increase in the human population (Barwegen 2005). In the post-independence period, it lasted until the 1980s before livestock development programmes started again. The government advised the farmers to form farmers' groups to exchange information and experiences on agricultural practices and to contact effectively support services. These farmers' groups continue till now. In Central Java, the local government launched many small ruminant development programmes, such as group housing, animal sharing programmes, slatted floors and village breeding units (Budisatria et al. 2007b). The group housing programme has not been successful. Households like to supervise their own small ruminants every day, and in some areas there was not sufficient land available to start group housing projects. A successful programme has been the introduction of slatted floors. These are considered to be more hygienic and offer the possibility to collect manure compost. In Central Java in the early 2000s, $40 \%$ (middle zone) to $70 \%$ (lowlands and uplands) of the interviewed farmers used a slatted floor, whereas 20 years earlier this was only $20 \%$ (Budisatria et al. 2007b). In the lowlands and uplands, bamboo sticks are used as slats; whereas in the middle zone, concrete and good quality timbers are used as slats. The perceived costs of slats explain why middle zone farmers have been reluctant to use slatted floors. The sharing programme promotes sharing rams owned by the government. In traditional sharing programmes, sheep owners lend animals to other farmers in return for a share of the lambs. An FAO earthquake rehabilitation project in Central Java made use of the potential role of sheep in improving livelihoods for the really poor by implementing the traditional animal sharing arrangements. Five sheep were distributed to a household hit by the earthquake in 2006, on the condition that they had to revolve the same number of sheep within 3 years. The project increased the number of sheep and the number of sheep farmers with $50 \%$ in the earthquake area in about 3-year time.

In Java, about $20 \%$ of rural households keep small ruminants. A comparison of households with small ruminants with their neighbours without them showed that the main reasons of the neighbours for not keeping small ruminants were lack of capital, insufficient family labour available and insufficient time available. Only few neighbours were not interested in small ruminants (Budisatria et al. 2007b). For a long time, small ruminants were in short supply in Indonesia. Recent government statistics show, however, that numbers of small ruminants could be higher than the small ruminant meat demand (Anonymous 2008). Recent research in Central Java showed that $72 \%$ of sheep slaughtered in slaughterhouses were productive females; consequently, many lambs are being lost (Budisatria et al. 2009). In recent years, government services address mainly cattle production in an effort to become self-sufficient in beef. There are no regular extension, credit or veterinary services geared towards small ruminant farmers. Efforts to make effective use of small ruminant production need to be facilitated by stronger institutions. Farmers need access to reliable and affordable support services, offering them access to knowledge and inputs, including credit and marketing information.

\section{Conclusions}

In Indonesia, the number of sheep has dramatically increased over the last 90 years. Gradually fat-tailed sheep have replaced the native thin-tailed sheep because of their larger body size and the consumers' preference for their meat, in particular their tail. Major changes occurred in management in response to the changes in resources, but the motives for keeping sheep have hardly changed. The cut-and-carry management system is labour intensive, so the number of sheep households can keep will always be 
limited. Sheep are not a main income earner for rural households, but, they are an essential livelihoods resource. Sheep fit farmer's household priorities and make use of available crop residues. Urgent cash needs for, e.g. school fees and preparation of paddy fields were main reasons for selling sheep. The availability of small ruminant manure compost is essential to sustaining the very intensive smallholder cropping systems on Java. Systematic sheep fattening can contribute to achieving higher economic results, if sufficient family labour and feed are available. It is surprising that sheep have been neglected in development programmes because of the preference for sheep to be sacrificed during religious festivities. Future developments will be shaped by changing consumer habits, intensification of farming practices, options outside agriculture and availability of support services.

Open Access This article is distributed under the terms of the Creative Commons Attribution Noncommercial License which permits any noncommercial use, distribution, and reproduction in any medium, provided the original author(s) and source are credited.

\section{References}

Anonymous, 2006. Livestock Statistics 2006 [Statistik Peternakan 2006], (Direktorat Jenderal Peternakan, Departemen Pertanian RI, Jakarta).

Anonymous, 2008. Livestock Statistics 2008 [Statistik Peternakan 2008], (Direktorat Jenderal Peternakan, Departemen Pertanian RI, Jakarta).

Asikin, A.S., 2001. Analisis pendapatan uisaha ternak domba ekor gemuk di Lembah Palu: Studi kasus pada petani/peternak miskin di Kecamatan Marawola, (MSc thesis, Universitas Gadjah Mada, Yogyakarta).

Barwegen, M., 2005. Gouden Horens. De geschiedenis van de veehouderij op Java, 1850-2000 [History of livestock in Java, 1850-2000] (PhD thesis Wageningen University, Wageningen).

Basuno, E. and Petheram, R.J., 1982. Ruminants ownership in four West Java hamlets, research report, (small ruminant-CRSP, Ciawi, Bogor).

Budisatria, I.G.S., 1996. Pengaruh frekuensi pemberian bekatul terhadap penampilan ternak domba, Laporan Penelitian. (Fakultas Peternakan, Universitas Gadjah Mada, Yogyakarta).

Budisatria, I.G.S., 2006. Dynamics of small ruminant development in Central Java, Indonesia ( $\mathrm{PhD}$ thesis Wageningen University, Wageningen).

Budisatria, I.G.S., Udo, H.M.J., Zijpp, A.J. van der, Murti, T.W. and Baliarti, E., 2007a. Air and water qualities around small ruminant houses in Central Java, Indonesia. Small Ruminant Research, 67, $55-63$.

Budisatria, I.G.S., Udo, H.M.J., Eilers, C.H.A.M., and Zijpp, A.J. van der, 2007b. Dynamics of small ruminant production: a case study of Central Java, Indonesia. Outlook on Agriculture, 36, 145-152.

Budisatria, I.G.S., Udo, H.M.J., Zijpp, A.J. van der, Baliarti, E. and Murti, T.W., 2008. Religious festivities and marketing of small ruminants in Central Java, Indonesia. Asian Journal of Agriculture and Development, 5, 57-74.

Budisatria, I.G.S., Kustono, A., and Bilqis, R.S., 2009. Slaughter rate of female sheep in Yogyakarta Province, proceedings of national seminar, (Faculty of Animal Science, Universitas Gadjah Mada, Yogyakarta).

Budisatria, I.G.S., Udo, H.M.J., Eilers, C.H.A.M., Baliarti, E. and Zijpp, A.J. van der, 2010. Preferences for sheep or goats in Indonesia. Small Ruminant Research, 88, 16-22.

Devendra, C., 2002. Crop-animal systems in Asia: future perspectives. Agricultural Systems, 71, 179-186.

DGLS, 2003. National Report on Animal Genetic Resources Indonesia: a strategic policy document, Directorate General of Livestock Services, (Department of Agriculture, Jakarta).

Gatenby, R.M., Jensen, R.A.C., Subandriyo and Bradford, G.E., 1988. Actual and potential levels of performance of Indonesian sheep and goats under traditional management systems, Technical Report Series No.97, SR-CRSP Indonesia/UC Davis, Bogor.

Gatenby, R.M., Wilson, A.J., Romjali, E., Pandey, V.S., Batubara, L.P. and Bradford, G.E., 1995. Helminth infections of sheep in rubber plantations in Sumatra. In: Gray, G.D., R.R. Woolaston and B.T. Eaton (eds), Breeding for resistance to infectious diseases in small ruminants (ACIAR, Canberra), 167-171.

Hernandez, R., 2006. Exterior characteristics of fat tailed sheep in Karanganyar district, Central Java, (MSc thesis, Fakultas Peternakan, Universitas Gadjah Mada, Yogyakarta).

Jabbar, M.A. 1998. Buyer preferences for sheep and goats in Southern Nigeria: a hedonic price analysis. Agricultural Economics, 18, 21-30.

Knipscheer, H.C., Boer, A.J. de, Sabrani, M. and Soedjana, T., 1983. The economic role of sheep and goats in Indonesia: a case study of West Java. Bulletin of Indonesian Economic Studies, 19, 7493.

Knipscheer, H.C., Kusnadi, U. and Boer, A.J. de, 1984. Some efficiency measures for analysis of the productive potential of Indonesian goats. Agricultural Systems, 15, 125-135.

Martawidjaja, M., Spinhoven, G. and Gatenby, R.M., 1982. The influence of shearing and giving concentrate on the performance of Javanese thin-tailed sheep, working paper No. 17, Research Institute for Animal Production (Small Ruminants-CRSP, Bogor).

Mason, I.L., 1978. Sheep in Java. World Animal Review, 27, 17-22.

Mason, I.L., 1980. Prolific tropical sheep, FAO Animal Production and Health paper No 17, (Food and Agriculture Organization of the United Nations, Rome).

Merkel, R.C., Simanihuruk, K., Ginting, S.P., Sianipar, J., Batubara, L.P. and Pond, K.R., 1999. Growth potential of five sheep genotypes in Indonesia. Small Ruminant Research, 34, 11-14.

Nasrullah, Yusmasari, A. Nurhayu, A.. Natsir, M.A., Asja, Murray-Prior, R. and Murray, P., 2010. Factors involved with the purchase of meat by consumers in Makassar, Sulawesi, Proceedings. 5th International Seminar on Tropical Animal Production, (Faculty of Animal Science, Universitas Gadjah Mada, Yogyakarta), 717-724.

Obst, J.M., Boyes, T. and Chaniago, T., 1980. Reproductive performance of Indonesian sheep and goats. Proceedings of the Australian Society of Animal Production, 13, 321-324.

Palte, J.G.L., 1989. Upland Farming on Java, Indonesia: a socioeconomic study of upland agriculture and subsistence under population pressure, Nederlandse Geografische Studies no. 97, (Utrecht University, Utrecht).

Pond, K.R., Sanchez, M.D., Horne, P.M., Merkel, R.C., Batubara, L. P., Ibrahim, T., Ginting, S.P., Burns, J.C. and Fisher, D.S., 1994. Improving feeding strategies for small ruminants in the Asian region. In: Subandriyo and R.M. Gatenby (eds.), Strategic Development for Small Ruminant Production in Asia and the Pacific, Proceedings of a Symposium held in conjunction with Seventh Asian-Australian Association of Animal Production Societies Congress, (AAAP, Denpasar, Bali, Indonesia), 77-97.

Rachman, R.N., Djajanegara, A. and Schüler, L., 2001. Selection to improve birth and weaning weight of Javanese fat tailed sheep. Archiv für Tierzucht, Dummerstorf, 44, 649-659. 
Robinson, D.W., 1977. Livestock in Indonesia, (Centre for Animal Research and Development, Bogor).

Sarwono, B.D., Dwipa, I.B.G., Media, I.G.L., and Poerwoto, H., 1993. Goat production in rice-based farming systems in Lombok. In: Subandriyo, Gatenby, R.M., (eds.). Advances in Small Ruminants Research in Indonesia. Proceedings of workshop held at the Research Institutes for Animal Production, (Ciawi-Bogor, Indonesia), 65-79.

Sodiq, A. and Tawfik, E.S., 2004. Productivity and breeding strategies of sheep in Indonesia: a review. Journal of Agriculture and Rural Development in the Tropics and Subtropics, 105, 7182.

Soedjana, T.D., 1982. Sheep and goat markets during Idul Adha in Bandung. Ilmu dan Peternakan, 1(2), (Research Institute for Animal Production, Bogor).

Soedjana, T.D., 1993. Economics of keeping small ruminant. In: Tomaszewska, M.W., I.M. Mastika, A. Djajanegara, S. Gardiner and T. Wiadarya (eds.). Produksi Kambing dan Domba di Indonesia. Sebelas Maret University Press, Solo, 367-401.
Soedjana, T.D., de Boer, A.J. and Knipscheer, H.C., 1988. Potential use of technologies for sheep and goat smallholder in Indonesia. Small Ruminant Research, 1, 249-258.

Subandriyo, 1998. Performance of Javanese thin tail sheep. IARD Journal 20(3), 65-71.

Tanner, J.C., Holden, S.J., Owen, E., Winugroho, M. and Gill, M., 2001. Livestock sustaining intensive smallholder crop production through traditional feeding practices for generating high quality manure-compost in upland Java. Agriculture, Ecosystems and Environment, 84, 21-30.

Thys, E. and Wilson, R.T., 1996. Age and sex composition of small ruminants at Nouakchott markets, Mauritania. Small Ruminant Research, 20, 281-284.

Winantea, A. and Udo, H.M.J., 1988. Fecundity in fat-tailed sheep at two different altitudes in East Java. Tropical Animal Health and Production, 20, 143-148.

Yulianto, A., 2007. Natural increase estimation of thin and fat tailed sheep in Klaten district, Central Java, (MSc thesis, Fakultas Peternakan, Universitas Gadjah Mada, Yogyakarta). 